\title{
THE RIGHT TO STRIKE AND THE "DEADWEIGHT" OF THE COMMON LAW
}

Shae McCrystal ${ }^{*}$

The hostility of the common law in respect of collective action by workers in the form of strikes is notorious. To provide workers with a right to strike, legislative intervention is necessary. In New Zealand and Australia, legislative enactment of the right to strike has taken the form of the "immunity approach" whereby strike action which meets the prerequisites for protection under the relevant statute receives immunity from common law action, while that which does not remains subject to potential liability at common law.

This article analyses the adoption of the immunity approach in Australia under the relevant federal industrial relations statutes that have operated since 1993. Commencing with discussion of the hostility of the common law to collective action and the principle of legality, a presumption of statutory interpretation that presumes Parliament would not have abrogated common law rights without an express intention to do so, this article examines how the scope of protected industrial action in Australia has been consistently narrowed through hostile judicial interpretation. Such interpretation has been grounded in an approach which narrows the extent that common law rights are restricted by the statute and construes the statutory enactment of a right to strike as conferring a "privilege" on those industrial actors who remain "worthy" enough to access it.

Considering the progressively negative impact on the right to strike of this approach, the argument in this article echoes calls made by Gordon Anderson in 1987 to reject the continued role of the common law in the regulation of industrial action. It is argued that the law of strikes in Australia should be codified. Such an approach should assist in downplaying judicial tendencies to interpret the right to strike as a privilege rather than as a necessary component of a functioning system of voluntary collective bargaining.

* Professor of Labour Law, The University of Sydney Law School. I would like to thank Richard Mitchell and Joellen Riley for their helpful comments on an earlier version of this article. 


\section{INTRODUCTION}

The hostility of the common law in respect of collective action by workers in the form of strikes is notorious. ${ }^{1}$ The formula for ascribing liability to workers and their unions is well understood. ${ }^{2}$ Strikes will almost always constitute a breach of contract on the part of the workers, leaving them liable to dismissal. Such breach of contract or threat thereof, when committed in concert with others, forms the "unlawfulness" element that fuels the economic torts. ${ }^{3}$ The economic torts form the jurisdictional basis to provide interlocutory injunctive relief to employers to stop threatened action in its tracks and subsequently ascribe liability to unions and their leaders in the event of an employer pursuing a tortious claim. ${ }^{4}$ Without statutory intervention, workers and unions are fully exposed to these potential liabilities in the event of strike action.

The necessity of statutory intervention to respect the rights of workers and their organisations to strike is well understood, as are the potential pitfalls of legislating in a piecemeal fashion against one common law liability at a time. As the history of the economic torts in the United Kingdom demonstrates, the common law has shown remarkable resilience and capacity for adaptation in the face of parliamentary attempts to nullify the effects of the economic torts. ${ }^{5}$ In 1987, the New Zealand Parliament enacted the Labour Relations Act 1987 which provided statutory protection for industrial action for the first time. The economic torts remained one of the remedies available to employers in respect of unlawful strike action. ${ }^{6}$ At the time, Gordon Anderson warned of the dangers posed by this

1 See Gordon Anderson "Strikes and the law: the problems of legal intervention in labour disputes" (1988) 13 NZJIR 21 at 21. The term "strike" conventionally refers to a total work stoppage, however a range of conduct short of a strike (for example work bans or work to rule campaigns instigated as a form of industrial disobedience) have the same consequences at law. For the sake of brevity, the term strike is here used to encompass both total work stoppage and industrial disobedience short of stoppage.

2 See Susan A Tacon Tort Liability in a Collective Bargaining Regime (Butterworths, Toronto, 1980) at 7; Simon Deakin and Gillian S Morris Labour Law (5th ed, Hart Publishing, Oxford, 2009) at 899-900; and Andrew Stewart and others Creighton \& Stewart's Labour Law (6th ed, The Federation Press, Sydney, 2016) at 941-944 and 953-959.

3 KD Ewing has observed that if a strike did not constitute a breach of contract, "this might eliminate liability by undermining the base of the economic torts": KD Ewing "The Right to Strike" (1986) 15 ILJ 143 at 151.

4 See Gordon Anderson "The Disadvantages of Injunctions in Industrial Disputes" [1975] NZLJ 179.

5 See Lord Wedderburn The Worker and the Law (3rd ed, Penguin Books, London) at ch 1; and Patrick Elias and Keith Ewing "Economic Torts and Labour Law: Old Principles and New Liabilities" (1982) 41 CLJ 321.

6 Labour Relations Act 1987, ss 233-234. The economic torts were first accepted by the New Zealand courts in the context of industrial disputation in a series of cases in the early 1970s: see Gordon Anderson, John Hughes and Dawn Duncan Employment Law in New Zealand (2nd ed, LexisNexis, Wellington, 2017) at 607608. 
retention of the economic torts as a mechanism for sanctioning unlawful strikes. ${ }^{7}$ Conscious of the insidious effect of the common law in the arena of industrial disputation, he called for New Zealand to jettison the common law by codifying the law of strike action, allowing for the development of a distinctly New Zealand law of strikes. ${ }^{8}$ Such law, he observed, could be as liberal or as restrictive as Parliament determined, but crucially, would be an important step in achieving a more "rational" law of strikes. ${ }^{9}$ Anderson's suggestion was never adopted, and in 2009 he observed that to "gain traction" any radical change to labour laws "has to overcome the philosophical deadweight of the common law". 10

In Australia, the shift from the systems of conciliation and arbitration to enterprise based collective bargaining included the capacity of workers and their organisations to take lawful strike action in support of negotiations for an enterprise level agreement. However, the common law continued to apply where the statutory requirements for lawfulness were not met. Workers and their organisations were granted immunity from the common law provided they played by the rules of the system. This approach is referred to here as the "immunity approach", where workers are provided with access to lawful strike action provided they comply with the statutory pre-requisites.

This article examines the implementation of the immunity approach to lawful strike action in the federal industrial relations system in Australia. It argues that this approach has contributed to narrowing the capacity of workers to take lawful strike action and facilitated an approach by the courts to statutory interpretation that treats lawful strike action as a privilege, with immunity accorded only to the "worthy". Retention of the common law has driven formalistic interpretation of successive legislative enactments. This article further argues that adoption of Anderson's codification approach would assist in eliminating underlying judicial hostility to collective action. This may promote an approach to the interpretation of provisions regulating strikes underpinned by recognition of the complexities of industrial negotiation, and the rough and tumble of voluntary collective bargaining.

This article will set out the relevant background, including the role of common law presumptions in respect of statutory interpretation. It then provides an overview of the implementation of the immunity approach in the federal industrial relations system, before examining a series of cases which demonstrate the problem with the "immunity approach". It concludes by suggesting that a different approach is required.

7 Gordon Anderson "The Reception of the Economic Torts into New Zealand Labour Law: A Preliminary Discussion" (1987) 12 NZJIR 89 at 92.

8 Anderson, above $\mathrm{n} 1$, at 30.

9 At 30 .

10 Gordon Anderson "The Capability Approach and the Legal Regulation of Employment: A Comment on Deakin" (2009) 34(1) NZJER 27 at 32. 


\section{COLLECTIVE LABOUR LAW AND THE COMMON LAW}

Australia and New Zealand have both implemented systems of voluntary collective bargaining for determination of terms and conditions of employment at the enterprise level. In such systems the parties to bargaining are considered best placed to determine the terms and conditions of future employment, and in that process they may access the tools of economic coercion - strikes and lockouts - to pressure the other party to concede their position. Without the potential for strike action, the greater powers of employers in respect of managerial prerogative, property rights and asset control would leave workers with very little leverage.

International recognition of the right of workers to form associations and act in association, including the right to strike, is found in art 8 of the International Covenant on Economic, Social and Cultural Rights, ${ }^{11}$ and in the Constitution and Conventions of the International Labour Organization (ILO). ${ }^{12}$ In respect of the latter, the right to strike is taken by the ILO supervisory bodies to be an essential component of the principles of freedom of association, and more specifically the right of workers to form associations, act in association and determine their own activities and programs is protected by Convention No 87, the Freedom of Association and Protection of the Right to Organise Convention. ${ }^{13}$

However, while the right of workers to take strike action is protected in international law and the logic of voluntary collective bargaining dictates that workers be given access to the strike weapon, the reality of industrial conflict may be politically and judicially unpalatable. In the exercise of strike action, third party interests may be affected, and managerial prerogative may be challenged. In Australia, the scope of lawful strike action has narrowed over time through the intervention of

11 International Covenant on Economic, Social and Cultural Rights 933 UNTS 3 (opened for signature 19 December 1966, entered into force 3 January 1976). Both Australia and New Zealand have ratified this Convention.

12 Membership of the International Labour Organization (ILO) entails commitment by member states to the principles of freedom of association which include the right to strike: see International Labour Organization Freedom of Association: Digest of decisions and principles of the Freedom of Association Committee of the Governing Body of the ILO (5th ed, International Labour Office, 2006) at [575].

13 See International Labour Organization Giving Globalisation a Human Face: International Labour Conference 101st Session, 2012 (International Labour Office, ILC.101/III/1B, 2012) at [117-119]. Australia has ratified Convention 87, but New Zealand has not. For discussion of recent controversy surrounding recognition of the right to strike at the ILO see Nicola Smit "International Developments Regarding the Implementation of the Right to Strike" (2017) 38 Comp Lab L \& Pol'y J 395. 
Parliament, ${ }^{14}$ and through the influence of restrictive judicial interpretation of key statutory provisions. $^{15}$

Underlying this restrictive judicial interpretation is a principle of statutory interpretation known as the principle of legality: ${ }^{16}$

Courts do not impute to the legislature an intention to abrogate or curtail certain human rights or freedoms

(of which personal liberty is the most basic) unless such an intention is clearly manifested by unambiguous

language.

One element of this principle is the well-known presumption of statutory interpretation that Parliament would not overthrow fundamental principles, infringe rights, or "depart from the general system of law, without expressing its intention with irresistible clearness". ${ }^{17}$ In the labour law context, the presumption suggests that common law rights of employers in respect of strike action by employees would not be overthrown or departed from "unless such an intention is clearly manifested". According to Pearce and Geddes, the philosophy underpinning the presumption is that it is the responsibility of the courts to protect the individual from the excesses of the state, such protection best being afforded by the principles of the common law. ${ }^{18}$ However, they also note that in an area like labour law where the notion of individuals being able to contract freely is "quite unrealistic" the presumption "may defeat the purpose of the legislation [being construed] and penalise the persons in whose favour the Act has been made". ${ }^{19}$ Further, Meagher has argued that there are no clearly established principles that guide judicial determination of the common law rights that benefit from the application of the presumption, and notes that in the application of the rule, other "rights and interests in the relevant legislative context" are not balanced or weighed. ${ }^{20}$ As such, the rule "operates to insulate (and so protect in full) the judicial conception of the common law right from the operation of the relevant legislation". ${ }^{21}$

14 See Shae McCrystal "Smothering the Right to Strike: Work Choices and Industrial Action" (2006) 19 AJLL 198.

15 See Leigh Johns "The Answer is: Not to Certify" (2004) 17 AJLL 317, discussing the High Court decision of Electrolux Home Products Pty Ltd v Australian Workers' Union [2004] HCA 40, (2004) 221 CLR 309.

16 Al-Kateb v Godwin (2004) 219 CLR 562 at 577 per Gleeson CJ.

17 Potter v Minahan (1908) 7 CLR 277 at 304 per O'Connor J; and Coco v R (1994) 179 CLR 427 at 437 per Mason CJ, Brennan, Gaudron and McHugh JJ. See also DC Pearce and RS Geddes Statutory Interpretation in Australia (8th ed, LexisNexis, Australia, 2014) at 236.

18 Pearce and Geddes, above n 17, at 236.

19 At 237.

20 Dan Meagher "The Common Law Principle of Legality in the Age of Rights" (2011) 35 MULR 449 at 462.

21 At 463 
The difficulty with an interpretative approach that "insulates" common law rights is that the common law protects the rights of the individual and private property, generally presumes equality in contracting relationships and exhibits hostility to collective action. ${ }^{22}$ The notions of "contract, property and employer's prerogative" are central to the common law, ${ }^{23}$ and, as Wedderburn has observed, judges may be unwilling to "bow the knee of the common law to a balance of power that offends its philosophy". ${ }^{24}$ Ryan and Walsh argue that the common law is based on assumptions that private ownership, managerial prerogative and the subordinate status of workers are inviolable. ${ }^{25}$ In a detailed analysis of the liability in tort of Canadian workers participating in a picket, Tacon observed that the approach of the courts was to focus on the elements of tort to the exclusion of relevant industrial factors such as provocation or unfair labour practices, ${ }^{26}$ elevating the protection of property rights over industrial ones. ${ }^{27}$ This echoes Meagher's observation that in construing common law rights, other rights or interests are not duly weighed or considered. ${ }^{28}$

Such underlying biases in the common law against collective labour rights has led to calls for greater autonomy for labour law. ${ }^{29}$ This has taken the form of suggestions that labour laws be administered only by labour courts or tribunals in order to allow for the development of area-specific expertise, providing for a more nuanced assessment of the problems of industrial disputation in judicial decision-making. ${ }^{30}$ Other commentators have suggested that the answer lies in codification

22 See also Claudia Geiringer "The Principle of Legality and the Bill of Rights Act: A Critical Examination of $R v$ Hansen" (2008) 6(1) NZJPIL 59 at 88 who notes that the principle of legality has been applied "in favour of a narrow vision of classical economic liberalism and against incursions from a modern, collectivist state".

23 Lord Wedderburn "Labour Law: Autonomy from the Common Law?" (1988) 9 Comp Lab L \& Pol'y 219 at 234. See also Bob Hepple who observes that the concept of contract utilised by courts is "inherently biased in favour of the so-called 'natural' rule making power of the employer": Bob Hepple "Restructuring Employment Rights" (1986) 15 ILJ 69 at 82.

24 Wedderburn, above 23, at 238.

25 Rose Ryan and Pat Walsh "Common Law v Labour Law: The New Zealand Debate" (1993) 6 AJLL 230 at 240.

26 Tacon, above n 2, at 1 . Similar views are also expressed by Ian Hunt who observes that legal thinking has "little sympathy for the idea that equality of bargaining power is required for procedurally just wage agreements": Ian Hunt "Right against Right: Are Current Legal Constraints on Trade Unions Justified?" (2001) 11(3) Labour \& Industry 55 at 66.

27 Tacon, above n 2, at 9.

28 Meagher, above n 20, at 462.

29 See Wedderburn, above n 23; and Ryan and Walsh, above n 25. Compare Richard A Epstein "A Common Law for Labour Relations: A Critique of the New Deal Labor Legislation" (1983) 92 Yale LJ 1357.

30 See for example Wedderburn, above n 23, at 248; Tacon, above n 2, at 12; and Bob Hepple "Labour Courts: Some Comparative Perspectives" (1988) 41 CLP 169. 
through the removal of the common law as a remedy in respect of industrial action. ${ }^{31}$ This view has been developed particularly in the various contributions of Keith Ewing, who has argued for a form of adjudication of labour disputes "which prevents or minimises the possibility of damaging judicial intervention". ${ }^{32}$ In 1982 (with Elias) he observed that "the continuing development of the common law and its impact on trade union action, must again raise fundamental questions about the value of a system of immunities for the protection of the freedom to strike", 33 and more recently in 2016 (with Hendy and Jones) he called for a change to the default rules such that "existing common law torts ... must give way ... and they should be abolished if necessary". ${ }^{34}$

How then has this problem manifested in Australia which implemented the immunity approach to legislating for strike action in 1993 ?

\section{THE "IMMUNITY APPROACH" IN AUSTRALIA}

Australia has a long and complex history in respect of the regulation of strike action. At the federal level, the Conciliation and Arbitration Act 1904 (Cth) famously prohibited strikes in the expectation that when industrial actors became unable to resolve disputes they would surrender the weapons of industrial coercion and seek a remedy through the newly instituted Court of Conciliation and Arbitration. ${ }^{35}$ When by 1930 it was apparent that this approach had failed to prevent strikes, the prohibition was repealed. ${ }^{36}$ In the following decades other statutory sanctions were tried with varying degrees of success, such that by 1991 the federal statute bristled with enforcement provisions, almost all of which were of "little or no relevance" in practice in respect of the daily conduct of industrial relations. ${ }^{37}$

31 See Anderson discussed at nn 7-10 and associated text.

32 Ewing, above n 3, at 156.

33 Elias and Ewing, above n 5, at 356.

34 Keith Ewing, John Hendy and Carolyn Jones (eds) A Manifesto for Labour Law: Towards a Comprehensive Revision of Workers' Rights (Institute for Employment Rights, Liverpool, 2016) at 52.

35 Henry Bournes Higgins "A New Province for Law and Order" (1915) 29 HLR 13 at 13-14.

36 Commonwealth Conciliation and Arbitration Amendment Act 1930 (Cth).

37 Breen Creighton "Enforcement in the Federal Industrial Relations System: an Australian Paradox" (1991) 4 AJLL 197 at 197. Likely in response to such a rise in employer action, in 1973 legislation was introduced to the Australian Parliament and the South Australian Parliament to provide immunity against tortious liability for unions acting in the course of an industrial dispute - however neither Bill passed into law. See RJ Mitchell "Liability in Tort for Causing Economic Loss by the Use of Unlawful Means and its Application to Australian Industrial Disputes" (1976) 5 Adel L Rev 428 at 429, n 8. 
During the conciliation and arbitration period, in addition to statutory sanctions, the common law applied to industrial disputes. ${ }^{38}$ For the most part, employers were generally unwilling to resort to the economic torts against unions and their members threatening or engaging in strike action, but this changed in the 1970s when employers began to make use of the full force of the law and the economic torts that had developed in the United Kingdom context were enthusiastically adopted by the courts. ${ }^{39}$

A crucial turning point for the law of strikes came in 1991 when the International Confederation of Air Line Pilots on behalf of the Australian Federation of Air Pilots (AFAP) complained to the ILO Governing Body's Committee on Freedom of Association (CFA) that the Australian system of conciliation and arbitration denied the AFAP and its members the right to strike. ${ }^{40}$ While ultimately the complaint was not upheld, the CFA did express concern that the prima facie unlawfulness of all strike action at common law could deprive Australian workers of the right to strike. ${ }^{41}$ This international attention, alongside a range of other factors that were driving a shift from conciliation and arbitration to enterprise level bargaining, led to the introduction in 1993 of legislative immunity from the common law for "protected industrial action" that met the requirements of the Act.

Statutory immunity at federal level was initially enacted through amendments to the Industrial Relations Act 1988 (Cth) (IR Act) in 1993. ${ }^{42}$ The Act was renamed the Workplace Relations Act (WR Act) in 1996, ${ }^{43}$ and substantially amended in 2006 by the Work Choices legislation. ${ }^{44}$ The WR Act was repealed in 2009, and the substantive provisions were replaced by the Fair Work Act 2009 (Cth) (FW Act). However, the overall contours of the legislative scheme in respect of protected industrial action have remained generally stable across time. ${ }^{45}$ An outline of the basic approach, noting

38 For discussion of the relationship between the conciliation and arbitration systems and the common law in respect of strike action in Australia see KD Ewing "The Right to Strike in Australia" (1989) 2 AJLL 18

39 WB Creighton, WB Ford and RJ Mitchell Labour Law: Text and Materials (2nd ed, Law Book Company, Sydney, 1993) at 1161-1171.

40 See Case No 1511 in Committee on Freedom of Association 277th Report of the Committee on Freedom of Association (International Labour Office, 1991).

41 See Case No 1511, above n 40; and Kathleen P McEvoy and Rosemary J Owens "On a Wing and a Prayer: The Pilots' Dispute in the International Context" (1993) 6 AJLL 1.

42 Industrial Relations Reform Act 1993 (Cth). Prior to 1993, the only Australian jurisdiction to have enacted a right to strike through the immunity approach was Queensland. Protection for trade unions from liability for the torts of conspiracy and inducing breach of contract applied from 1915 to 1961 in s 28 of the Trade Union Act 1915 (Qld) and from 1961-1976 in ss 70-72 of the Industrial Conciliation and Arbitration Act 1961 (Qld). See Shae McCrystal The Right to Strike in Australia (The Federation Press, Sydney, 2010) at 69-70.

43 Workplace Relations and Other Legislation Amendment Act 1996 (Cth).

44 Workplace Relations (Work Choices) Amendment Act 2005 (Cth).

45 An overview from 1993-2010 is set out in McCrystal, above n 42, at ch 4. See also Shae McCrystal "A New Consensus: The Coalition, the ALP and the Regulation of Industrial Action" in Anthony Forsyth and Andrew 
significant variations, suffices as a foundation for the discussion to follow. The current provisions are found in Part 3-3 of the FW Act.

During bargaining for an enterprise level collective agreement, employees and their representatives may take "protected industrial action" in support of their claims provided that the relevant jurisdictional prerequisites have been met. "Industrial action" has been defined in the various iterations of the legislation to include both total work stoppages and a wide range of action short of total work stoppage. ${ }^{46}$ The jurisdictional prerequisites to industrial action constituting "protected industrial action" are:

- The action taken is industrial action within the statutory definition.

- The party seeking to take industrial action has been, and is, genuinely trying to reach an agreement at the enterprise concerned.

- The industrial action is taken in support of the proposed enterprise agreement

- The industrial action is not taken in support of pattern bargaining (industrial action by a bargaining representative and the employees they represent at multiple enterprises in support of common claims in the negotiations at those enterprises).

- The industrial action is not taken while an enterprise agreement is in force at the relevant enterprise.

- The industrial action is not taken in support of "unlawful terms" which cannot be included in an enterprise agreement.

- The bargaining representative has not contravened any orders in relation to bargaining that apply to them.

- Since 2006, the industrial action has been authorised by the relevant employees in a ballot, such ballot having been ordered by the federal tribunal, and the action authorised commences within 30 days of the declaration of the ballot result. ${ }^{47}$

- The appropriate notice of industrial action has been given to the employer, and the action that is taken is the action of which notice was given.

Stewart (eds) Fair Work: The New Workplace Laws and the Work Choices Legacy (The Federation Press, Sydney, 2009) 141.

46 The definition is currently found in s 19 of the Fair Work Act 2009 (Cth) [FW Act]. See Breen Creighton, Catrina Denvir and Shae McCrystal "Defining Industrial Action" (2017) 45 FL Rev 383.

47 See Breen Creighton, Catrina Denvir and Shae McCrystal "Strike ballots and the law in Australia" (2016) 29 AJLL 154. 
- $\quad$ Protected industrial action has not relevantly been suspended or terminated by an order of the federal tribunal.

Where the requirements for protected industrial action have been met, the relevant legislative immunity applies. The immunity has remained essentially unchanged since it was introduced in $1993,{ }^{48}$ and is currently enacted in s 415(1) of the FW Act, providing that:

No action lies under any law (whether written or unwritten) in force in a State or Territory in relation to any industrial action that is protected industrial action unless the industrial action has involved or is likely to involve:

(a) Personal injury; or

(b) Wilful or reckless destruction of, or damage to, property; or

(c) The unlawful taking, keeping or use of property.

The protection does not extend to the law of defamation in relation to anything occurring in the course of industrial action. ${ }^{49}$ In respect of individual employees, protection against "adverse action" in the form of dismissal or prejudice in employment for having participated in protected industrial action is found in the FW Act "general protection" provisions. ${ }^{50}$

Where industrial action is taken that is unprotected, the statutory immunity does not apply, and employees are not protected against dismissal or other adverse consequences. Some unprotected action, for example action taken during the currency of an enterprise agreement, is expressly unlawful and subject to civil penalties under the Act. ${ }^{51}$ However, except for industrial action in the building and construction industry, ${ }^{52}$ there is no express statutory prohibition of unprotected industrial action. Instead, under the statutory scheme that applied from 1996-2005, the federal tribunal had a discretionary power to make orders against unprotected action, requiring either that it stop, not occur

48 See Industrial Relations Act 1988 (Cth) [IR Act], s 170PM as amended by the Industrial Relations Reform Act 1993 (Cth).

49 FW Act, s 415(2).

50 FW Act, ss 340-342. In 1993 employees were protected in respect of industrial action taken pursuant to an industrial dispute - no distinction was drawn between protected and unprotected action: IR Act, s 334A as amended by the Industrial Relations Reform Act. This was repealed in 1996 after which protection extended only to protected industrial action. However, the value of this protection must be questioned in light of the High Court decision in Construction, Forestry, Mining and Energy Union v BHP Coal Pty Ltd (2014) 253 CLR 243: see Joellen Riley "General Protections: Industrial Activities and Collective Bargaining" in Shae McCrystal, Breen Creighton and Anthony Forsyth (eds) Collective Bargaining under the Fair Work Act (The Federation Press, Sydney, 2018) 162.

51 See the FW Act, s 417.

52 Unprotected industrial action was expressly prohibited in the building and construction industry under s 37 of the Building and Construction Industry Improvement Act 2005 (Cth) from 2005-2012 and has been unlawful since 2016 under s 46 of the Building and Construction Industry (Improving Productivity) Act 2016 (Cth). 
or not be organised. ${ }^{53}$ Since 2006, the federal tribunal has been required by the statute to make an order against any unprotected industrial action that is happening; threatened, impending or probable or is being organised. ${ }^{54}$ The significance of an order is that a breach constitutes a civil penalty offence enforceable in the Federal Court. ${ }^{55}$ Further, as common law rights and remedies still apply, unprotected action will immediately be subject to those potential liabilities.

The discussion will now consider aspects of this statutory scheme in more detail, examining the influence of common law rights on its interpretation over time.

\section{RELATIONSHIP BETWEEN THE STATUTORY SCHEME FOR INDUSTRIAL ACTION AND THE COMMON LAW}

Since the enactment of the protected industrial action regime in 1993, aspects of the regime, particularly in respect of its relationship with the common law, have been interpreted narrowly by the courts, leading to a tightening or restriction of the capacity lawfully to strike over time. While the judicial direction has not been all one way, ${ }^{56}$ the approach of the courts has been consistent with the idea that the grant of immunity against otherwise applicable common law action is a privilege and access to this privilege is to be restricted. The right to strike, the realities of industrial conflict and the general messiness of collective bargaining are almost universally ignored.

This approach of the courts can be illustrated by looking at decisions concerning the statutory scheme for protected industrial action, and those with respect to unprotected industrial action.

\section{$V$ THE STATUTORY SCHEME FOR PROTECTED INDUSTRIAL ACTION}

As outlined above, the scheme of protected industrial action relies on industrial action satisfying different prerequisites to attract the protection of the immunity provisions. The influence of the common law and the idea that protection against common law liability operates as a "privilege" has been most apparent in how the courts have approached interpretation of the prerequisites across time. Courts have generally construed them narrowly, without due regard to context, the overall legislative scheme or the degree of complexity within the system. This has led to a number of cases where industrial actors have failed to meet the prerequisites for immunity, despite their genuine and consistent efforts to do so.

53 See Victor Di Felice "Stopping or Preventing Industrial Action in Australia" (2000) 24 MULR 310.

54 Workplace Relations Act (Cth) [WR Act], s 496; and the FW Act, s 418.

55 FW Act, ss 421(1) and 539.

56 See for example the Full Federal Court in JJ Richards \& Sons Pty Ltd v Fair Work Australia [2012] FCAFC 53, (2012) 201 FCR 297, discussed in Leigh Howard "Industrial action as a means to compel employers to commence bargaining" (2013) 26 AJLL 214. 
To fall within the scope of protection under the various iterations of the legislative scheme, the action notified and taken must be industrial action under the statutory definition. This has included (across the various enactments) action involving a "ban, limitation or restriction on the performance of work, or on acceptance of or offering for work". ${ }^{57}$ The text of the definition is very broad and a literal interpretation would encompass a picket carried out by employees and their union as a "ban, limitation or restriction" on the performance of their own work. This would have the effect that a picket undertaken during a work stoppage would attract the protection of the immunity provision, provided that it did not involve personal injury, damage to property or action constituting defamation and that tribunal orders against pickets constituted during unprotected industrial action would also be available.

However, this is not the approach that has prevailed. Instead, the Full Court of the Federal Court in Davids Distribution Pty Ltd v National Union of Workers, referring specifically to the principle of legality, construed the definition of industrial action to avoid a finding that it included a picket. ${ }^{58}$ Attempting to ensure that the impact of common law rights and remedies in respect of conduct on a picket would not be diminished, the Court referred to the lack of any "clear indication" in the statute at the time that Parliament had intended to abrogate common law rights in this respect. ${ }^{59}$ It further observed that to find a picket to be covered by the definition of industrial action (a finding that was open on the wording of the statute) would "substitute, for a remedy in common law courts ... a mere right to apply to the Commission for an order prohibiting the conduct". ${ }^{60}$ In other words, Parliament would not have intended to abrogate common law rights and replace them with a mere statutory right.

This approach by the Federal Court remains authoritative. ${ }^{61}$ However, as commentators have noted, the decision "clearly favours established common law rights and remedies over broad rights conferred by statute", 62 and was based on a "fundamental misunderstanding of the purpose of the statutory provisions", ${ }^{63}$ which were designed specifically to abrogate common law rights. Given the whole purpose of the provisions is to provide immunity against "any law (whether written or unwritten) in force in a State or Territory", ${ }^{64}$ it seems incongruous for the Court to have presumed

57 This definition is currently enacted as FW Act, s 19(1)(b).

58 Davids Distribution Pty Ltd v National Union of Workers [1999] FCA 1008, (1999) 91 FCR 463.

59 At 491.

60 At 491

61 See Stewart and others, above n 2, at 930 .

62 John Howe "Picketing and the Statutory Definition of 'Industrial Action"' (2000) 13 AJLL 84 at 90.

63 Creighton, Denvir and McCrystal, above n 46, at 410.

64 FW Act, s 415(1). 
that Parliament expressed no intention to abrogate common law rights in respect of a picket, a common and long-established feature of industrial campaigns in Australia.

The next example arises out of the 1997 decision of the Victorian Supreme Court in National Workforce Pty Ltd v Australian Manufacturing Workers' Union. ${ }^{65}$ At the time, one of the prerequisites to protected industrial action (since repealed) was a requirement that employees and their representatives have not engaged in the action "in concert with one of more persons or organisations that are not protected persons". ${ }^{66}$ Three unions involved in negotiations for new enterprise agreements with a group of labour hire companies sought to take protected industrial action. Two of the unions failed to meet the prerequisites, and consequently their action was unprotected. However, the employer brought an application for injunctive relief against the third union, the Australian Manufacturing Workers' Union (AMWU) which believed that it had complied with the statutory prerequisites, on the basis that the AMWU was engaging in the action "in concert" with the other two unions. At first instance, Harper J refused the grant of injunctive relief, concluding that the existence of a generally recognised right to strike was relevant to the exercise of his discretion in granting interlocutory relief and that there was an available remedy under the statute (orders against unprotected industrial action) for the employer if the action was unprotected. ${ }^{67}$

On appeal, the Full Court of the Supreme Court overturned this decision, rejecting the inclusion of a generally recognised right to strike as relevant to the exercise of discretion in granting an injunction, and instead referred to the important role of the court in these cases in "vindicating private rights". ${ }^{68}$ With respect to the AMWU's attempt to take protected industrial action, the Court gave little consideration to the fact that the AMWU had itself complied with everything that it needed to do to be protected under the WR Act, had fully intended to act lawfully and had no control over the actions of the other unions involved. Instead, it simply observed that the AMWU had failed to comply with the statutory prerequisites and as a consequence the employer's rights at common law could not be diminished or affected by appeals to notions concerning the right to strike. ${ }^{69}$

The decision in National Workforce was interlocutory only; however it marked an early reluctance on the part of the courts to interpret the protected industrial action provisions expansively, or to

65 National Workforce Pty Ltd v Australian Manufacturing Workers' Union (1997) 76 IR 200 (VSC) [National Workforce Pty Ltd (VSC)].

66 WR Act, s 170MM(1). However, the requirement does appear in s 8(2) of the Building and Construction Industry (Improving Productivity) Act for protected industrial action in that industry.

67 National Workforce Pty Ltd v Australian Manufacturing Workers' Union (1997) 75 IR 200 (VSCA).

68 National Workforce Pty Ltd (VSC), above n 65, at 279.

69 At 279. See further Stuart Kollmorgen "Qualifying the Statutory Right to Strike" (1998) 11 AJLL 128. 
consider that the implementation of the right to strike should have any impact outside of the statutory scheme itself.

Electrolux Home Products Pty Ltd v Australian Workers' Union, by contrast, is a decision of the High Court. ${ }^{70}$ Here the High Court considered whether protected industrial action could be taken in support of claims which were not capable of inclusion in an enterprise agreement. By way of context, the content of claims that are capable of inclusion in an enterprise agreement has long been a matter of difficulty in the federal industrial regime. The law in this area is complex, confused and often contradictory. It is possible for a union to have a reasonable and genuine belief that claims can be included in an enterprise agreement, even though it is subsequently found that the claims do not meet the statutory criterion for inclusion. ${ }^{71}$ If the High Court found that action in support of non-permitted claims could not be protected, employees and their representatives would not be able to ascertain with any certainty that proposed industrial action would be protected. Further industrial action that was thought to be protected could be rendered unprotected, even years after the event, by a later ruling on the content of permissible claims. ${ }^{72}$

Faced with two reasonably open competing interpretations of the WR Act from the Federal Court at first instance, ${ }^{73}$ and on appeal to the Full Federal Court, ${ }^{74}$ the High Court concluded that industrial action which supported claims which were not capable of inclusion in a certified agreement could not constitute protected industrial action. ${ }^{75}$ In preferring the interpretation which restricted the scope of protected industrial action, both Gleeson CJ and McHugh J referred to the presence of parliamentary intention to curtail the common law rights of parties affected by industrial action, but found that a more restrictive reading of the statute was consistent with the principle of legality in statutory interpretation. ${ }^{76} \mathrm{~A}$ similar approach was also apparent in the joint judgment of Gummow, Hayne and Heydon $\mathrm{JJ},{ }^{77}$ although without express endorsement of the principle of legality as an element of their interpretative approach, and to a lesser extent Callinan $\mathrm{J}^{78}$ In respect of the genuine likelihood that

70 Electrolux Home Products Pty Ltd v Australian Workers' Union [2004] HCA 40, (2004) 221 CLR 309 [Electrolux Home Products Pty Ltd (HCA)].

71 See Stewart and others, above n 2, at 365-369.

72 Johns, above n 15, at 325 .

73 Electrolux Home Products Pty Ltd v Australian Workers' Union [2001] FCA 1600.

74 Automotive, Food, Metals, Engineering, Printing and Kindred Industries Union v Electrolux Home Products Pty Ltd [2002] FCAFC 199, (2002) 118 FCR 177.

75 Electrolux Home Products Pty Ltd (HCA), above n 70.

76 At 357-358 per McHugh J and 328-329 per Gleeson CJ.

77 At 367-368 per Gummow, Hayne and Heydon JJ.

78 At 398 per Callinan J. 
parties could take industrial action based on an "honest and reasonable, but mistaken, belief" that their claims were capable of inclusion in an agreement, McHugh $\mathrm{J}$ observed that this made no difference to the case and the action would remain unprotected. ${ }^{79}$

By contrast, Kirby $\mathrm{J}$ in dissent observed that it was "a serious mistake of interpretation to read the scope of the protection afforded by the Act in a way favoured by the majority" as such an interpretation was "impractical" and "incompatible with the context and with Parliament's language and purpose". 80 In particular Kirby $\mathrm{J}$ noted that the majority approach effectively defeated the specific remedial protection against civil liability afforded to unions under the Act. ${ }^{81}$

Ultimately in Electrolux an approach which preserved common law rights was preferred to one which was in keeping with the language and purpose of Parliament, which would offer certainty to employees and their representatives in engaging in protected industrial action, and which would ensure that parties who made a genuine effort to comply with the complex statutory scheme were protected. ${ }^{82}$

In 2017 the High Court was again called upon to consider the scope of the prerequisites to protected industrial action in Esso Australia v The Australian Workers' Union. ${ }^{83}$ As in Electrolux, the case involved a point of statutory interpretation, upon which there were two reasonably open competing interpretations, one of which would have the effect of substantially narrowing the scope of protected industrial action.

The issue revolved around s 413(5) of the FW Act which provides that it is a prerequisite to protected industrial action that a bargaining representative must not have "contravened any orders that apply to them" in respect of matters arising during bargaining for that agreement. A union which believed their action to be protected had contravened an order of the tribunal during bargaining. This contravention had subsequently been rectified. When the union then sought to take protected industrial action, the employer objected, arguing that the contravention of the order disqualified the union from taking protected industrial action for the remainder of the negotiations.

79 At 358 per McHugh J. Notably, this concept of reasonable belief was incorporated into s 409(1) of the FW Act in 2009.

80 At 380 per Kirby J.

81 At 380 per Kirby J.

82 See Jason Harris "Federal Collective Bargaining After Electrolux" (2006) 34 FL Rev 45.

83 Esso Australia v The Australian Workers' Union [2017] HCA 54, (2017) 92 ALJR 106 [Esso Australia (HCA)]. 
At first instance in the Federal Court, ${ }^{84}$ and on appeal to the Full Federal Court, ${ }^{85}$ the interpretation that prevailed was that the section only applied to a bargaining representative who was in breach of a relevant order at the time they sought to take protected industrial action. This approach would allow parties to rectify any breaches of orders and retain access to the protected industrial action provisions during bargaining for that agreement.

On appeal to the High Court, it was acknowledged that the section was poorly drafted, and could reasonably be interpreted in one of two ways: either to prevent protected industrial action by a bargaining representative (and relevant employees) currently in contravention of an order (as preferred in the Federal Court), or to prevent any protected industrial action by a bargaining representative (and relevant employees) where any order of the tribunal or a court had been breached during the course of bargaining for that agreement.

The High Court, by majority, found that the section prevented protected industrial action in the event of any breach (inadvertent, technical or otherwise) of an order of the tribunal or a court during bargaining for that agreement. In support of this interpretation, the majority referred to the legislative history and statutory context. In terms of the scheme of the Act, they referred to the immunity as a "privilege" and claimed that the "apparent purpose" of s 413(5) "is to ensure that persons who have shown they cannot be trusted to comply with orders ... are not to be trusted with the immunity afforded in relation to protected industrial action". ${ }^{86}$

Gageler J, in dissent, also observed that in interpretation of the provision, the purpose and policy of the statutory scheme must be given due weight. ${ }^{87}$ However, in contrast to the majority, Gageler $\mathrm{J}$ emphasised the complexity of the scheme of collective bargaining. Noting that the scheme of bargaining and industrial action under the FW Act contains a large number of potential orders that may be made by a tribunal, all of which may be easily, inadvertently or technically breached by parties during collective bargaining, such breaches must be expected in the scheme, and often may easily be remedied or only short lived. ${ }^{88}$ In such a context, the interpretation of the majority would lead to s 413(5) operating as a "harsh and rigid form of industrial discipline" likely to create industrial cripples

84 Esso Australia v The Australian Workers' Union [2015] FCA 758, (2015) 253 IR 304.

85 Esso Australia v The Australian Workers' Union [2016] FCAFC 72, (2016) 245 FCR 39.

86 Esso Australia (HCA), above n 83, at 123 per Keifel CJ, Keane, Nettle and Edelman JJ.

87 At 126 per Gageler J.

88 At 128. 
and outlaws. ${ }^{89}$ Gageler $\mathrm{J}$ found that this was not consonant with a statutory scheme designed to create an environment for collective bargaining that is "fair and flexible and efficient". ${ }^{90}$

At the beginning of his judgment, Gageler $\mathrm{J}$ expressly eschewed any presumptions of interpretation based on the common law, observing that "[n]o grand common law presumption is engaged". ${ }^{91}$ He construed the provision within its industrial context expressly acknowledging the complexities of collective bargaining, the role of industrial action and the multiplicity of available orders under the FW Act. Gageler J's preferred outcome reflects industrial reality and recognises that there are no "worthy" or "wronged" parties in industrial relations, only complex power relations that require flexible responses. By contrast, the judgment of the majority begins with the common law history, reciting the observation that industrial action is generally unlawful at common law, ${ }^{92}$ and ends with a defence of the common law and an assertion that protection against liability at common law is a privilege. ${ }^{93}$ In this interpretation, industrial outcomes are black and white, with only the "worthy" deserving protection.

The approach to interpretation evident within the decisions under discussion is that it does not matter to what extent an employee bargaining representative intends to comply with the statute or acts in good faith in pursuit of their industrial rights. In meeting the statutory criteria, unintentional, inadvertent failures, or those outside of the control of the parties themselves, will not be excused and the statute will be interpreted strictly and in defence of the common law. Given that the consequence otherwise will be to deny common law rights and remedies, a restrictive interpretation consistently prevails, despite the fact that the legislative scheme seeks to give effect to a competing set of industrial rights. In keeping with Meagher's observation discussed above, these are rarely weighed in the balance.

\section{UNPROTECTED INDUSTRIAL ACTION}

As noted above, outside of the building and construction industry, there has been no express prohibition of unprotected industrial action in federal legislation since 1930. Instead, common law rights and remedies have been available to employers, and in the period since 1996, the tribunal has had the power to make orders against unprotected action (being compelled to do so since 2006).

When the scheme was first enacted in 1993, the IR Act included s 166A, a provision which restricted the capacity of employers to bring "an action in tort ... in relation to conduct ... in contemplation or furtherance of claims that are the subject of an industrial dispute" unless the

89 At 132 .

90 At 132 .

91 At 126 .

92 At 116 per Keifel CJ, Keane, Nettle and Edelman JJ.

93 At 116 
employer had first attempted to conciliate the dispute before the tribunal, and such conciliation had failed to resolve the dispute within 72 hours. ${ }^{94}$ Given that the pursuit of proceedings in respect of a tortious right of action may take years to come to judgment, the point of instituting this 72 hour delay was to prevent the employer from obtaining an interlocutory injunction from a court against unprotected industrial action by the employees and their union. Thus, the legislative scheme at the time, particularly given the history of the arbitration system, was an attempt to resolve industrial disputes before the courts became involved. It was also intended to go some of the way to addressing criticisms raised by the ILO supervisory bodies over how easy it was to obtain interlocutory relief against strike action. ${ }^{95}$

However, the practical and intended effect of s 166A was quickly overcome by the willingness of the courts to grant injunctive relief against unprotected industrial action without conciliation having taken place on the basis that s 166A only prohibited the commencement of an "action in tort", not an action in equity seeking an interlocutory injunction. As observed by Beach J in Patrick Stevedores No 1 Pty Ltd v Maritime Union of Australia, "application for injunctive relief is not an action in tort under the law of the State of Victoria". 96 This highly technical approach defended the jurisdiction of the courts in respect of interlocutory relief against tortious action. However, it also had the effect of depriving s 166A of the WR Act of any meaning or practical effect. In Patrick Stevedores Operations Pty Ltd v Maritime Union of Australia, Wood CJ referred to the presumption of legality, finding nothing in the parliamentary debates surrounding the introduction of s 166A to support the view that it applied to actions for injunctive relief. ${ }^{97}$ However, in that attempt, his Honour made no attempt to construe the legislative scheme or draw the obvious conclusion that his preferred interpretation would deprive the section of any meaning.

Section 166A was eventually repealed in 2005 as part of the Work Choices package of amendments, which also involved a significant tightening of the approach taken to unprotected industrial action. ${ }^{98}$ As noted above, the discretion of the federal tribunal to make orders against unprotected industrial action was removed, with the consequence that the tribunal was required to make an order against unprotected industrial action once it became aware of it. Further, the repeal of

94 This was the wording that applied after the Act was amended by the Workplace Relations and Other Legislation Amendment Act.

95 Breen Creighton and Andrew Stewart Labour Law: An Introduction (3rd ed, The Federation Press, Sydney, 2000) at 414 .

96 Patrick Stevedores No 1 Pty Ltd v Maritime Union of Australia (1998) 79 IR 268 (VSC) at 271. See also Patrick Stevedores Operations Pty Ltd v Maritime Union of Australia (1998) 82 IR 87 (WASC) at 89-90; and Patrick Stevedores Operations Pty Ltd v Maritime Union of Australia (1998) 82 IR 237 (NSWSC) [Patrick Stevedores Operations Pty Ltd (NSWSC)].

97 Patrick Stevedores Operations Pty Ltd (NSWSC), above n 96, at 245.

98 See further McCrystal "Smothering the Right to Strike: Work Choices and Industrial Action", above n 14. 
s 166A removed any (largely theoretical) barrier to the commencement of a common law claim or a pursuit of an interlocutory injunction.

However, one part of this statutory scheme that has thus far not been mentioned is the prohibition of coercion. Originally enacted as s $170 \mathrm{NC}$ of the WR Act in 1996, it is currently found in s 343 of the FW Act. The 1996 version of the prohibition provided that a person must not take or threaten to take any industrial action or other action "with intent to coerce" another person to agree or not to agree in respect of making an enterprise agreement. The current provision is in similar terms but only refers to "any action" (rather than specifically identifying industrial action). The provision expressly does not apply to protected industrial action.

The purpose of this provision in the legislative scheme is difficult to detect. As industrial action is, by its very design, intended to be coercive of the will of the employer in respect of the making of a collective agreement, on a literal interpretation of the section it would be easy to conclude that the provision makes all unprotected industrial action unlawful and potentially immediately subject to the imposition of a civil penalty under the Act. However, if this was Parliament's purpose in enacting the provision, why not simply enact a prohibition against unprotected industrial action, as Parliament has done in respect of unprotected industrial action in the building and construction industry? ${ }^{99}$ Furthermore, how does this approach fit alongside the role of the tribunal in making orders that unprotected industrial action cease, with civil penalties following only once an order has been breached? As illustrated above, it is easy unintentionally to fall foul of one of the prerequisites for protected industrial action while genuinely trying to comply. In such a case is there the requisite intent to commit this offence? What if the industrial action taken is not actually intended to "coerce" in the sense of negating the will of the employer, but only to irritate or disrupt in order to demonstrate depth of support for the union's position amongst the employees? Would this be relevantly coercive? ${ }^{100}$

The answer, according to the High Court, is yes. That is to say, that irrespective of the overall statutory scheme for protected industrial action, the nature of the industrial action involved or an otherwise legitimate intention to take protected industrial action, all unprotected industrial action will be relevantly coercive and a breach of the statute.

This outcome was first observed by the High Court in Electrolux. Despite acknowledging that a union which thought it had taken protected industrial action might inadvertently fail to do so, and only discover this a long time later, it observed that the action would likely also breach the prohibition

99 See $\mathrm{n} 52$.

100 For example, by sending emails in caps lock or taking lunch breaks in management offices. See Breen Creighton and Shae McCrystal "Esso Australia Pty Ltd v The Australian Workers' Union: Breaches of Orders, Coercion and Protected Industrial Action under the Fair Work Act 2009 (Cth)" (2017) 39 SLR 233 at 242. 
against coercion. ${ }^{101}$ This view was given without reference to the scheme of the Act or potential competing interpretations of the section.

In Esso the High Court affirmed that the term "coercion" was to be interpreted in accordance with the meaning of common law economic duress such that action will be relevantly coercive if it is unlawful, illegitimate or unconscionable, and is taken with an intent to influence an employer to enter into a proposed agreement (amongst other things). ${ }^{102}$ For this purpose it does not matter if the union otherwise intended to take lawful action - if it did not, for whatever reason, it will breach the provision. This conclusion was drawn by using a common law definition to give meaning to the statutory term "coercion" without full consideration of the statutory scheme surrounding industrial action, or of the ease with which a party can fall foul of the protected industrial action provisions. The effect of the decision is to render all unprotected industrial action unlawful as a breach of the FW Act, an outcome that is not obvious on the face of the Act or the overall scheme for the regulation of industrial action.

\section{CONCLUDING OBSERVATIONS - THE "DEADWEIGHT" OF THE COMMON LAW}

This discussion has demonstrated the pernicious effect of retaining the common law as one component of the scheme for regulating industrial action. Under the prevailing immunity approach, the ability to impose sanctions on unions and employees at common law for unprotected industrial action has driven a legalistic interpretation of the statutory regime. This interpretation has jealously guarded those common law rights and consistently narrowed the circumstances in which they can be avoided. The principle of legality, including the presumption that Parliament must have clearly and expressly intended to override common law rights, has been used to erode the scope of the immunity, despite the fact that in enacting the immunity, Parliament has been unequivocal in its elevation of the right to strike over the common law.

The idea as expressed by the majority of the High Court in Esso that the system of industrial regulation enacted in the FW Act rewards those who are worthy with protection from common law liability, leaving those who cannot be trusted on the industrial fringe without access to protected industrial action, is anathema to a fair and flexible system of voluntary collective bargaining. In referencing common law rights and remedies in reaching the conclusion that protected industrial action is a privilege, the High Court majority confirmed how deeply the common law bias runs and how after 25 years of a protected industrial action regime, the common law continues to act as a restricting limitation on statutory enactment of the right to strike.

101 Electrolux Home Products Pty Ltd (HCA), above n 70, at 373 per Gummow, Hayne and Heydon JJ.

102 Esso Australia (HCA), above n 83, at 124. 
What then is the answer when legislating for a right to strike? One solution could be expressly to oust the principle of legality as a direction to courts in respect of the interpretation of the statute. However, as the discussion of unprotected industrial action demonstrates, the problem is deeper than that, with the common law influencing interpretation of the statute even without application of the principle itself. The approach taken to interpretation of the offence of coercion, through the use of common law concepts to produce an outcome at odds with the statutory scheme, suggests that this approach would not be sufficient.

The answer surely lies in codification, as Anderson suggested in 1987, and which is echoed in the calls of Ewing to consider jettisoning the common law. Codification would not necessarily provide a more expansive right to strike, as various legislative enactments in Australia over the history of the protected industrial action regime have demonstrated. But it would signal clearly to the courts that the common law is no longer to act as a deadweight on the industrial regime and should play no role in statutory interpretation. It would also allow for the development of a more rational approach, especially with respect to the difficult problem of the relationship of the statutory scheme and unprotected industrial action.

Codification would require the Australian Parliament to grapple with some difficult questions, particularly concerning the impact of unprotected industrial action on the contract of employment and the provision of remedies for employers in such circumstances where access to the economic torts was removed. These debates are worth having to lead to a more logical and consistent approach to the regulation of all industrial action. This should involve a more flexible approach to the interpretation of the scope of protected industrial action provisions and removal of judicial tendencies to see the right to strike as a privilege rather than a necessary, if messy, component of a functioning system of voluntary collective bargaining. 
